\title{
A Comparison of Escherichia coli Data Collected in False Creek by Metro Vancouver and Fraser Riverkeeper
}

\author{
Anastasia Wilcott ${ }^{1}$, Helen Heacock ${ }^{2}$, Lorraine McIntyre ${ }^{3}$ \\ 1 Lead Author, B. Tech Student of Health Sciences, British Columbia Institute of Technology, 3700 Willingdon \\ Ave, Burnaby, BC V5G 3H2 \\ 2 Supervisor, School of Health Sciences, British Columbia Institute of Technology, 3700 Willingdon Ave, Burnaby, \\ BC V5G 3H2 \\ 3 Contributor, British Columbia Centre of Disease Control, 655 West 12th Ave, Vancouver, BC
}

\begin{abstract}
Background: False Creek is a small inlet centered within Vancouver, British Columbia. Its long and narrow shape facilitates the build-up of contaminants and limits dilution of fresh water. The lack of flushing coupled with sources of fecal contamination results in high levels of Escherichia coli particularly in the summer months. High levels of $E$. coli in recreational water pose a health hazard to the public. Two organizations Metro Vancouver and Fraser Riverkeeper monitored E. coli levels in False Creek over the 2018 summer season.

Methods: Data collected by Metro Vancouver and Fraser Riverkeeper over the 2018 summer season was collected and compared. The secondary data was analyzed from July 8, 2018 to September 29, 2018 from thirty-day geometric means. Each organization sampled on a weekly basis in False Creek, Metro Vancouver sampled from twelve locations and Fraser Riverkeeper sampled from seven locations. Both organizations used similar methodologies in the collection of data with both analyzing for microbiological enumerations of most probable number [MPN] of E. coli per 100/mL samples. All sample sites were divided into three locations representative of False Creek: West, Central and East. The data was then analyzed in terms of overall weekly samples by organization, locational weekly samples by organization and locational weekly samples overall.
\end{abstract}

Results: The data was analyzed using an Aspin Welch Unequal Variance T-test to compare the overall weekly $E$. coli counts between the organization. Where $\mathrm{p}=0.000$ and power $=1.00$. An Equal Variance T-test was used to compare the locational weekly E. coli counts from the West, Central and East regions of each organization. This yielded a $\mathrm{p}=0.000$ where power $=1.00$. A Kruskal Wallis One-Way ANOVA was used to compare the locational weekly E. coli counts from the West, Central and East regions. This found $\mathrm{p}=0.000$ and power $=1.00$. A MANOVA was used as a reiteration to compare the weekly E. coli counts at each location (West, Central and East) when collected by each organization. This confirmed the same p-value and power results from the three previous tests.

Conclusions: There is a statistically significant difference between the two organizations. Not only in overall samples but there is a statistically significant difference between the two organizations when E. coli is amalgamated by location. When accounting for location only, the East region obtained statistically higher E. coli counts as the mean E. coli count for West was 90.8, Central was 248 and East was 1040.

Keywords: Vancouver, Canada, Escherichia coli, water quality, recreational water, public health

\section{INTRODUCTION}

This study will compare data collected from

Metro Vancouver and the Fraser Riverkeeper

regarding water quality in False Creek. Specifically, this study will compare the collections methods, collection locations and total E. coli data between the two locations. The reason for doing this study is to compare data as requested by the $\mathrm{BC}$ Center for

Disease Control [BCCDC]. Every year the BCCDC

looks for relevant opportunities to examine public health and have decided this topic should be looked into. By conducting this study, the BCCDC may advise Metro Vancouver, Vancouver Coastal Health, Fraser Riverkeeper and other parties tied to False 
Creek how best to interpret their data. Furthermore, this may lead to a merger between the two collectors of data to increase efficiency and save resources.

\section{LITERATURE REVIEW}

\section{Factors Indicative of Water Quality:}

Fecal indicator bacteria [FIB] such as E. coli and enterococci has long served as an indicator for presence of fecal contamination. Though other FIB exist such as total coliforms, fecal coliforms and fecal streptococci, traditionally E. coli and enterococci have been used to measure sewage contamination in bodies of water to protect the public from recreational waterborne illnesses [RWI] caused by bacteria, protozoa and viruses (Health Canada, 2012). False Creek is a salt water system therefore enterococci should be measured as it is the best indicator of salt marine water and E. coli are best measures of fresh water (Health Canada, 2012). However, the data used for this project collected from total E. coli therefore E. coli will be discussed in this literature review.

\section{Sources of Contamination in False Creek:}

False Creek is a small inlet centered within Vancouver. It divides downtown from South Vancouver. Science World is located at its eastern end, with three bridges passing above from West to East: Burrard, Granville and Cambie. The Canada Line tunnel crosses underneath False Creek just west of the Cambie Bridge. It is home to Granville Island, popular tourist locations as well as the recently developed Olympic Village. The inlet is approximately $3 \mathrm{~km}$ long, varies between $100 \mathrm{~m}$ and $400 \mathrm{~m}$ in width and a mean depth of $5 \mathrm{~m}$ (Ministry of Environment, 2006). It is one of the four major bodies of water a part of Vancouver along with English Bay, Burrard Inlet and the Fraser
River. There are many sources of pollution and factors which contribute to its bacterial count. These factors include the industrial history of False creek, sewage overflow and False Creek's poor ability to circulate fresh sea water.

\section{Pollutants in False Creek:}

Pollutants are defined as substances which are introduced and sometimes accumulate in environments which cause undesired effects.

Combined Sewer Overflows, stormwater outfalls, raw effluent disposed by boaters and the natural design of False Creek all contribute to its water quality.

\section{Combined Sewer Overflows [CSOs] are} sewers that contain both sewage and stormwater coming from one pipe. CSOs ideally are not used and the waste is sent to one of five wastewater treatment facilities within the Lower Mainland (Balanced Environmental Services, 2010). However, when precipitation is high, the plants cannot handle the increased flow and so to prevent a sewage back-up the combined wastewater is discharged without any treatment. There are two CSOs that expel into False Creek: Crowe St. East and Heather St.

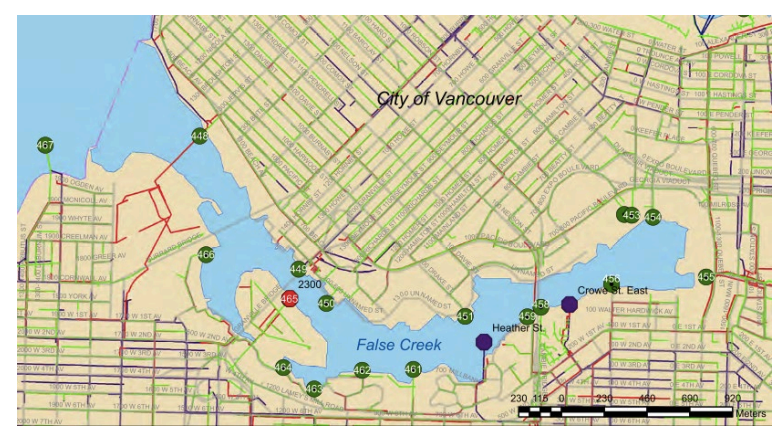

Figure 1: A map of False Creek indicating the location of CSOs, stormwater outfalls and permitted effluent as indicated in purple, green and red respectively (Balanced Environmental Services, 2010).

CSOs can have varying levels of impact depending on the volume of water available to dilute 
the concentration of effluent. When measuring the contaminant loading in False Creek, Hall et al. (1999) found the Crowe St. East CSO required the largest dilution compared to other CSOs to mitigate its impact. This is despite the fact that discharge volume was relatively small and due to the small volume available in False Creek to dilute its contaminants. Compatively, Passerat et al. (2011) measured E. coli and enterococci from a single CSO in the Seine river (France) and with the average measure being $1.5 \times 10^{6} \mathrm{E}$. coli and $4.0 \times 10^{5}$ intestinal enterococci per $100 \mathrm{~mL}$. While CSOs clearly have a negative impact on the water quality in False Creek, over the past decades Vancouver has been switching to separate sanitary and stormwater sewers to reduce CSOs. Additionally, a provincial regulation is requiring Vancouver to eliminate all CSOs by 2050 at a rate of 1\% per year (Crowe \& Eng,. 2014).

In addition to CSOs, stormwater alone is also excreted into False Creek. There are currently 16 stormwater outflows and one permitted effluent of stormwater discharging into False Creek (Refer to Figure 1). Municipalities do not measure stormwater discharges, making it difficult to estimate the local impact of stormwater alone in False Creek. Though stormwater poses less of a hazard as they are not combined with human waste as CSOs, it can pick up chemicals, pesticides, metals, petroleum products, sediment, and human and animal fecal wastes as it travels through Urban areas (Anh et al. 2005). Though no direct studies on E. coli or enterococci were found in Vancouver as of yet, Cummings (2016) isolated dog strains of E. coli from False Creek, suggesting stormwater runoff is carrying and introducing animal feces into the waters.

Additionally, Parker et al. (2010) quantified the total E. coli and enterococci from stormwater in North
Carolina and found storm water contained elevated levels of E. coli and enterococci, both of which exceeded the recreational water quality guidelines. Just as stormwater has been shown to contribute to poor water quality, illegal sewerage disposal by boaters is also a contributing factor. When making suggestions to improve False Creek, booth Horner (2017) and Cummings (2016) agreed illegal disposal by boaters was a contributing factor to the high E. coli counts in False Creek. The evidence to support this claim came from elevated levels of E. coli following a 2006 British Columbia Ministry of Environment [BCMOE] report on the impact boaters have. Within the twelve marinas in False Creek only five provide pump-out stations making it difficult for all boats with holding tanks to continually dispose of sewage. Another factor to consider is the number of boats moored outside of marinas but within the bay, particularly during the summer when temperatures support E. coli growth and boating is more popular. Whether or not these free-standing boats have holding tanks many may still avoid travelling to pump-out facilities each time their tanks are full due to the inconvenience and instead discharge raw sewage into the inlet. The volume of raw sewage contributed by boaters in False Creek cannot be calculated due to lack of information of the number of individuals living on boats, the length of time spent on their boats, the volume of water available to users of the boat and the proportion of boaters who do not use pump-out facilities.

The impact of these pollutants is only exaggerated by the low flushing rate of the inlet. False Creek is long and narrow in shape and has very limited inflow of fresh water. This minimizes water circulation to outside waters. Finally, the mean depth of 5 metres within the bay and the sill beneath 
Cambie Bridge causing a mean dept of 3 metres leads to poor circulation between the east and west ends of False Creek (Antony et al. 2015).

Despite these pollutants, recent spawning of herring eggs in False Creek suggest perhaps the water quality is improving due to conservational efforts.

John Matsen of the Squamish Streamkeepers Society hung artificial spawning nets within Fisherman's Wharf and this summer was able spawn an estimated 700 million eggs (Eagland, 2018). Perhaps with less sources of pollutants from CSOs, stormwater and raw sewage from boaters, False Creek water quality can improve.

\section{Current Legislation on Recreational Waters in}

\section{Vancouver:}

Recreational waters can cause a health hazard to the public through microbial contamination facilitating the spread of pathogens. For this reason, the legislation behind recreational waters will be summarized. Water quality guidelines for bacteriological indicators exist from a number of different agencies, including B.C. Ministry of Health, the Canadian Council of Ministers of the Environment (CCME), Health Canada and the World Health Organization (WHO) to help determine recreational standards for public use (British Columbia Ministry of Environment and Climate Change Strategy, 2017. Canadian Council of Ministers of the Environment, 2008. Health Canada, 2012. World Health Organization, 2006).

Health Canada's Guidelines for Canadian Recreational Water Quality is the most significant as it pertains directly to Canadians and was prepared by the highest power of government. The key issues addressed in this guideline is the importance of a multi-barrier approach, the importance of monitoring and recommended water quality parameters. The multi-barrier approach is when many factors are introduced to treat water, it is advantageous as it reduces public health concerns, improves recreational water organization and provides better management during emergencies and outbreaks (Health Canada, 2012). Proper monitoring and reporting are needed to ensure the quality of water and to effectively communicate its findings to the public. Health Canada (2012) advises E. coli should be monitored for fresh water and enterococci for marine water; Additionally, E. coli counts should not exceed a geometric mean of $200 \mathrm{E}$ coli $/ 100 \mathrm{~mL}$ nor a single sample of $400 \mathrm{E}$ coli/100mL.

\section{Fraser Riverkeeper:}

The Fraser Riverkeeper is a non-profit organization and partner of Swim Drink Fish Canada whose goal is to maintain and protect natural waters for the benefit of wildlife, drinking water and recreational use (Fraser Riverkeeper, 2018). As a licensed member of the Waterkeeper Alliance its major focuses are on public education of local waters in the Metro Vancouver and Fraser Valley area and monitoring the microbiological activity of False Creek. Water literacy is accomplished through workshops, beach clean-up events and most recently the launch of the Swim Guide App in which users can learn and report on the hazard rating of local beaches (Fraser Riverkeeper, 2018).

\section{Vancouver Coastal Health:}

Vancouver Coastal Health is one of six regional health authorities in $\mathrm{BC}$ which provides a range of health services in the Greater Vancouver and the Coast Garibaldi area. These services encompass, public health, primary care, acute care, community 
services, mental health, addictions and research (Vancouver Coastal Health, 2017).

Vancouver Coastal Health interprets data collected by all Metro Vancouver beaches to measure its compliance with the Canadian Recreational Water Quality Guidelines, 2012 (Vancouver Coastal Health, 2014). As per the guidelines, the goal of this monitoring program is to ensure locations that permits primary contact activities does not occur in waters where test results show a level greater than or equal to $200 \mathrm{E}$. coli bacteria per $100 \mathrm{~mL}$ of water.

Primary contact activities are when the whole body or face are immersed and when water will likely be swallowed. If test results exceed the recommended values or a hazardous event such as a spill occurs, the location will be assessed to determine the most suitable course of action in the best interest of the public. For example, the Medical Health Officer may require local government to post warning signs and beach closures that inform the public of the unsafe nature due to $E$. coli contamination (Vancouver Coastal Health, 2014). Included in this monitoring are three locations within False Creek: West, Central and East. Samples are collected weekly from May to September by Metro Vancouver and the City of Vancouver on behalf of Vancouver Coastal Health and are tested by BCCDC for E. coli testing.

\section{MATERIALS AND METHODS}

The materials used for this experiment involved collecting secondary data of microbiological enumerations of most probable number (MPN) of $E$. coli per $100 / \mathrm{mL}$ samples from multiple locations across False Creek collected by two unique organizations: Metro Vancouver on behalf of Vancouver Coastal Health and Fraser Riverkeeper between July 1 and September 29, 2018. Data was obtained by requesting it from both respective parties. By using secondary data, this made the comparison cost effective and efficient. Additionally, this made the experiment less prone to bias as data was collected prior to when the research question was posed. These samples were used generate a geometric mean over a five-week period. Geometric means are more appropriate compared to arithmetic means as they indicate the central tendency of a set of numbers to account for unusually high or low values (Zadeh et al., 2016).

The samples collected were analyzed for discrepancies and similarities between location and organization. The data analyzed was collected from July 8, 2018 to September 29, 2018. With twelve weeks between July and September and a total of nineteen locations this made for a total number of 228 samples.

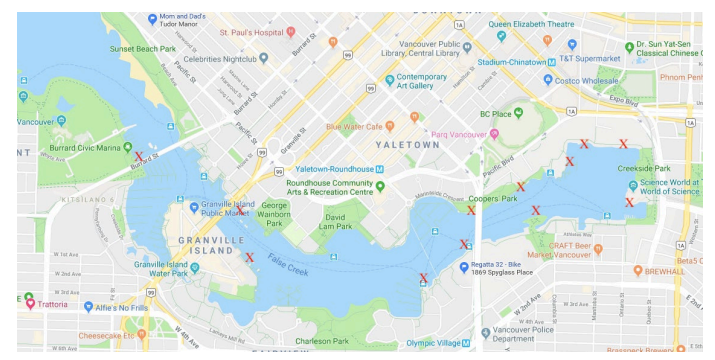

Figure 1: A map showing collection locations by Metro Vancouver for Vancouver Coastal Health from West to East: BFC-01-16, BFC-01-18, BFC-01-23, BFC-03-17, BFC-03-19, BFC-03-24, BFC-02-20, BFC-02-20A, BFC-02-21, BFC-02-22, BFC-02-25 and $\mathrm{BFC}-02-26$.

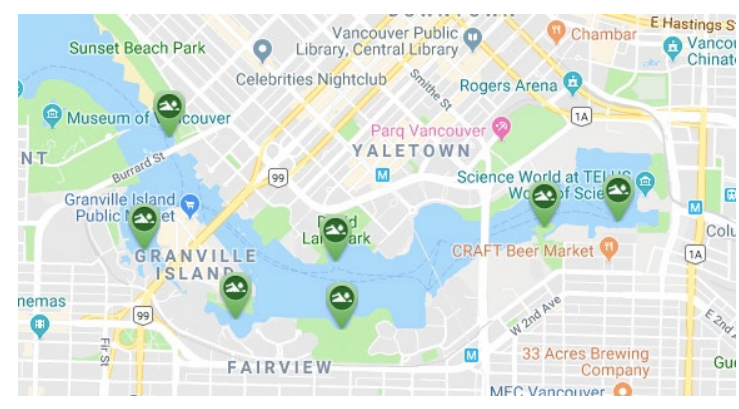

Figure 2: A map showing collection locations by Fraser Riverkeeper from West to East: Sunset Beach, Brokers' Bay, Alder Bay, David Lam Park, Charleson 
Park, Habitat Island and Olympic Village (Fraser Riverkeeper, 2018). Contrarily, Vancouver Coastal Health collects from twleve locations: West, Central and East.

VCH organizes its collected samples to generate geometric means for three locations in False Creek: West, Central and East. This gives a better understanding of the whole area as the E. coli counts are not uniform in distribution across False Creek. The West region are all samples sites West of George Wainborn Park. The Central region are all sample sites between George Wainborn Park and the Cambie Street Bridge. The East region are all sample sites east of the Cambie Street Bridge. The Fraser Riverkeeper sample site locations were also categorized by region as well. When determining how to divide the sample site locations, the same approach as to how $\mathrm{VCH}$ defines each region was taken. As such, the East location encompassed Sunset Beach, Brokers Bay and Alder Bay, the Central location encompassed David Lam Park and Charleson Park and the East location encompassed Habitat Island and Olympic Village.

\section{STATISTICAL ANALYSIS AND RESULTS}

\section{Description of Data}

Seeing as this data represents numbers on a scale that have a meaningful zero, the kind of data used in this statistical analysis is numerical ratio (Sauro and Lewis, 2012). The data was presented as geometric means of E. coli counts Vancouver Coastal Health and Fraser Riverkeeper calculated, though a recalculation was done to confirm results.

\section{Descriptive Statistics}

E. coli counts for each location collected by each organization were translated into geometric means using Microsoft ${ }^{\circledR}$ Excel. As seen in Table One and Three, geometric means calculated included weekly geometric means for each location (West, Central and East), overall geometric means calculated from data in Tables two and four and regional geometric means.

Table 1: VCH data collected by Metro Vancouver represented by geometric means.

\begin{tabular}{|c|c|c|c|c|c|}
\hline $\begin{array}{l}\text { Week } \\
\text { of: }\end{array}$ & $\begin{array}{l}\text { West, } \\
\text { Central } \\
\text { \& East } \\
\text { Geomean }\end{array}$ & $\begin{array}{l}\text { All MV } \\
\text { locations } \\
\text { Geomean }\end{array}$ & $\begin{array}{l}\text { Geomean } \\
\text { West }\end{array}$ & $\begin{array}{l}\text { Geomean } \\
\text { Central }\end{array}$ & $\begin{array}{l}\text { Geomean } \\
\text { East }\end{array}$ \\
\hline $\begin{array}{l}\text { Aug } \\
5-11\end{array}$ & 444.3 & 647.3 & 119.1 & 367.9 & 2001.4 \\
\hline $\begin{array}{l}\text { Aug } \\
12- \\
18\end{array}$ & 480.3 & 683.6 & 162.0 & 346.8 & 1971.3 \\
\hline $\begin{array}{l}\text { Aug } \\
19- \\
25 \\
\end{array}$ & 586.4 & 841.5 & 199.1 & 407.2 & 2486.5 \\
\hline $\begin{array}{l}\text { Aug } \\
26- \\
\text { Sept } \\
1\end{array}$ & 526.4 & 751.2 & 141.1 & 473.9 & 2181.9 \\
\hline $\begin{array}{l}\text { Sept } \\
2-8\end{array}$ & 335.9 & 588.2 & 79.7 & 338.0 & 1407.6 \\
\hline $\begin{array}{l}\text { Sept } \\
9-15\end{array}$ & 295.2 & 413.8 & 62.7 & 359.8 & 1139.7 \\
\hline $\begin{array}{l}\text { Sept } \\
16- \\
22\end{array}$ & 323.7 & 479.6 & 44.3 & 489.6 & 1560.2 \\
\hline $\begin{array}{l}\text { Sept } \\
23- \\
29\end{array}$ & 306.9 & 398.1 & 41.3 & 529.9 & 1321.6 \\
\hline
\end{tabular}

Table 2: Fraser Riverkeeper data represented by geometric means.

\begin{tabular}{|l|l|l|l|l|l|}
\hline $\begin{array}{l}\text { Week } \\
\text { of: }\end{array}$ & $\begin{array}{l}\text { West, } \\
\text { Central } \\
\text { \& East } \\
\text { Geomean }\end{array}$ & $\begin{array}{l}\text { All FRK } \\
\text { locations } \\
\text { Geomean }\end{array}$ & $\begin{array}{l}\text { Geomean } \\
\text { West }\end{array}$ & $\begin{array}{l}\text { Geomean } \\
\text { Central }\end{array}$ & $\begin{array}{l}\text { Geomean } \\
\text { East }\end{array}$ \\
\hline $\begin{array}{l}\text { Aug } \\
5-11\end{array}$ & 91.3 & 87.52 & 67.6 & 58.7 & 191.8 \\
\hline $\begin{array}{l}\text { Aug } \\
12-\end{array}$ & 153.5 & 145.8 & 107.0 & 93.0 & 362.9 \\
18 & & & & & \\
\hline $\begin{array}{l}\text { Aug } \\
19- \\
25\end{array}$ & 258.6 & 236.8 & 139.4 & 136.1 & 911.9 \\
\hline $\begin{array}{l}\text { Aug } \\
26- \\
\text { Sept } \\
1\end{array}$ & 194.7 & 177.2 & 101.0 & 134.0 & 544.8 \\
\hline $\begin{array}{l}\text { Sept } \\
2-8\end{array}$ & 142.7 & 133.9 & 91.4 & 110.3 & 288.1 \\
\hline $\begin{array}{l}\text { Sept } \\
9-15\end{array}$ & 71.6 & 66.8 & 43.9 & 57.5 & 145.6 \\
\hline $\begin{array}{l}\text { Sept } \\
16-\end{array}$ & & & & & \\
22 & 51.2 & 46.4 & 30.4 & 41.8 & 105.5 \\
\hline $\begin{array}{l}\text { Sept } \\
23- \\
29\end{array}$ & 31.0 & 28.7 & 21.9 & 28.8 & 47.3 \\
\hline
\end{tabular}

\section{Inferential Statistics}

Inferential statistics were used to compare the E. coli counts found between each region (West, Central and East) and between the two organizations, Vancouver Coastal Health and Fraser Riverkeeper tests used 
included a two sample T-test, an analysis of variance [ANOVA] and a multivariate analysis of variance [MANOVA] using the NCSS12® software (NCSS 12, 2018).

Table 3: Results of inferential statistics generated by NCSS 12 data analysis.

Ho1: There is no difference in the overall weekly E. coli counts collected by Metro Vancouver and Fraser Riverkeeper between July and September 2018.

$\mathbf{H}_{\mathrm{A1}}$ : There is a difference in the overall weekly E. coli counts collected by Metro Vancouver and Fraser Riverkeeper between July and September 2018.

Test Used: Aspin Welch Unequal Variance T-test Results: $\mathrm{P}=0.000$; Power $=1.000$

Conclusion: $\mathrm{P}=0.000$, therefore reject $\mathrm{H}_{\mathrm{O}}$ and we conclude there is a statistically significant difference between the two organizations. The mean E. coli count for VCH was 600 and FRK 115, hence Metro Vancouver obtained statistically higher E. coli counts.

Ho2: There is no difference in the locational weekly E. coli counts collected by Metro Vancouver and Fraser. Riverkeeper.

$\mathbf{H}_{\mathbf{A 2}}$ : There is a difference in the regional weekly E. coli counts collected by Metro Vancouver and Fraser Riverkeeper.

Test Used: Equal Variance T-test

Results: $\mathrm{P}=0.000$; Power $=1.00$

Conclusion: $\mathrm{P}=0.000$, therefore eject $\mathrm{H}_{\mathrm{O}}$ conclude there is a statistically significant difference between the two organizations when $E$. coli is amalgamated by region. The mean e.coli count for Metro Vancouver was 412 and Fraser
Riverkeeper 124, hence Metro Vancouer obtained statistically higher $E$. coli counts.

Ho3: There is no difference in the weekly E. coli counts between the West, Central and East locations.

$\mathbf{H}_{\mathrm{A3}}$ : There is a difference in the weekly E. coli counts between the West, Central and East locations.

Test Used: Kruskal Wallis One-Way ANOVA

Results: $\mathrm{P}=0.000$; Power $=1.00$

Conclusion: $\mathrm{P}=0.000$, therefore reject $\mathrm{H}_{\mathrm{O}}$ and conclude there is a statistically significant difference between the three locations. The mean E. coli count for West was 90.8, Central was 248 and East was 1040, hence East obtained statistically higher E.coli counts.

Ho4: There is no difference between the weekly $E$. coli counts at each location (West, Central and East) when collected by Metro Vancouver or Fraser Riverkeeper.

$\mathbf{H}_{\mathrm{A} 4}$ : There is a difference between the weekly $E$. coli counts at each location (West, Central and East) when collected by Metro Vancouver or Fraser Riverkeeper.

Test Used: MANOVA

Results: Organization: $\mathrm{P}=0.000$; Power $=1.00$; Location $\mathrm{P}=0.000$; Power $=1.00$; Organization and Location: $\mathrm{P}=0.000$; Power $=1.00$

Conclusion: Organization: $\mathrm{P}=0.000$, therefore reject $\mathrm{H}_{\mathrm{O}}$ and conclude there is a statistically significant difference between the two organizations. The mean E. coli count for Metro Vancouver was 760 and Fraser Riverkeeper 161, hence Metro Vancouver obtained statistically higher E. coli counts.

Location: 
$\mathrm{P}=0.000$ therefore reject $\mathrm{H}_{\mathrm{O}}$ and conclude there is a statistically significant difference between the three locations. The mean E. coli count for West was 90.8, Central was 248 and East was 1040, hence East obtained statistically higher E.coli counts.

Location and Organization:

$\mathrm{P}=0.000$ therefore reject $\mathrm{H}_{\mathrm{O}}$ and conclude there is a statistically significant difference between the three locations when collected by each organization. The mean E. coli count for West was 106, Central was 414 and East was 1760 when collected by Metro Vancouver, whereas for Fraser Riverkeeper was 75 for West, 83 for Central and 325 for East. We conclude there is a statistically significant difference between location and organization.

\section{DISCUSSION}

The purpose of this research study was to compare and analyze results of $E$. coli count in False Creek between two organizations, Metro Vancouver and Fraser Riverkeeper.

In all hypotheses tested, a statistically significant difference was identified. The first hypotheses found organizations are statistically different from one another in overall weekly samples. Despite controlling for the difference in the number of sampling stations by location in False Creek, there is still a difference in E. coli counts between the two organizations. This is shown as the mean E. coli count for Metro Vancouver was 600 and Fraser Riverkeeper 115, hence Metro Vancouver obtained statistically higher E. coli counts fivefold that of Fraser Riverkeeper.

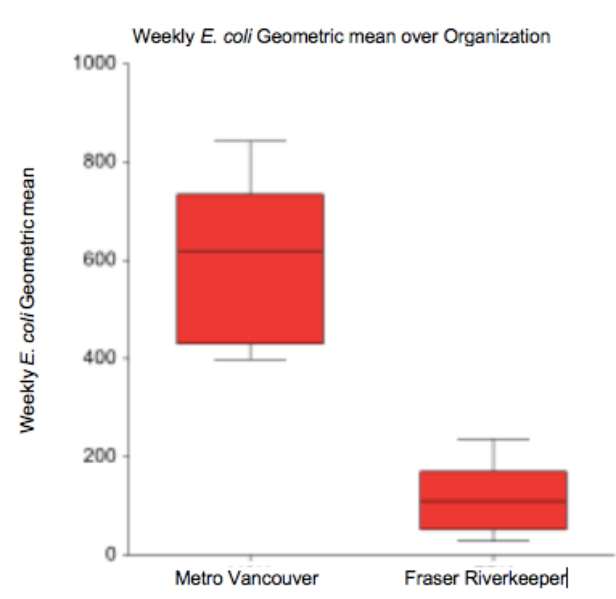

Figure 3: NCSS boxplot results of Aspin Welch Unequal Variance T-test.

When comparing the regional weekly E. coli counts, a statistically significant difference between the organizations at each location was concluded. This is shown as the mean E. coli count for Metro Vancouver was 412 and Fraser Riverkeeper 124, hence Metro Vancouver obtained statistically higher E. coli counts by nearly fourfold. This comparison differs from the first hypothesis as it accounts for the bias between the uneven number of sampling locations between each region and location. For example, Metro Vancouver's East region has five sampling locations whereas the West and Central regions each have three which may skew the geometric mean higher.

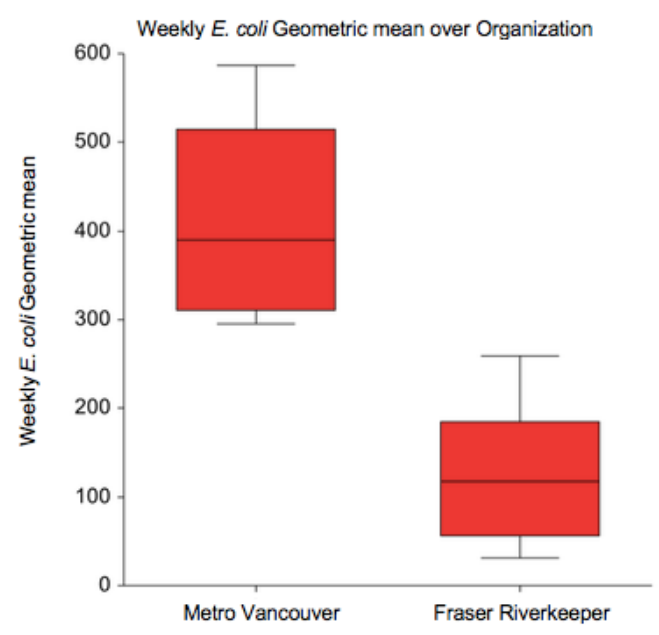


Figure 4: NCSS boxplot results of Equal Variance Ttest which accounted for the difference number of sampling locations each organization had.

Though the organizations compared were different, each captured the trend of gradually higher E. coli counts from West to East. This is again exemplified in the difference between weekly E. coli counts of the West, Central and East locations. The mean E. coli count for West was 90.8, Central was 248 and East was 1040, hence East obtained statistically higher E. coli counts. From the Scheffe test we see that West significantly differs from East, Central significantly differs from East and East significantly differs from West and Central.

However, West does not differ from Central.

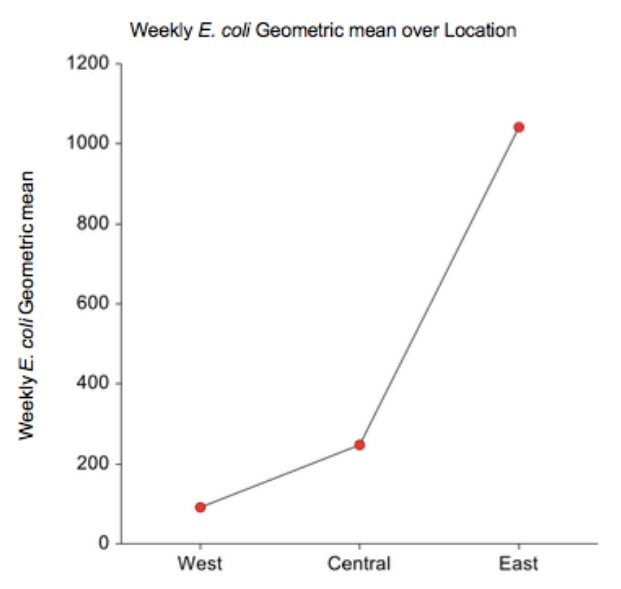

Figure 5: NCSS graph results of Kruskal Wallis One-Way ANOVA between all three locations. The final hypothesis reiterates the findings from the previous T-test and ANOVA analysis and confirmed there is a difference between the weekly $E$. coli counts at each location (West, Central and East) when collected by Metro Vancouver or Fraser Riverkeeper.

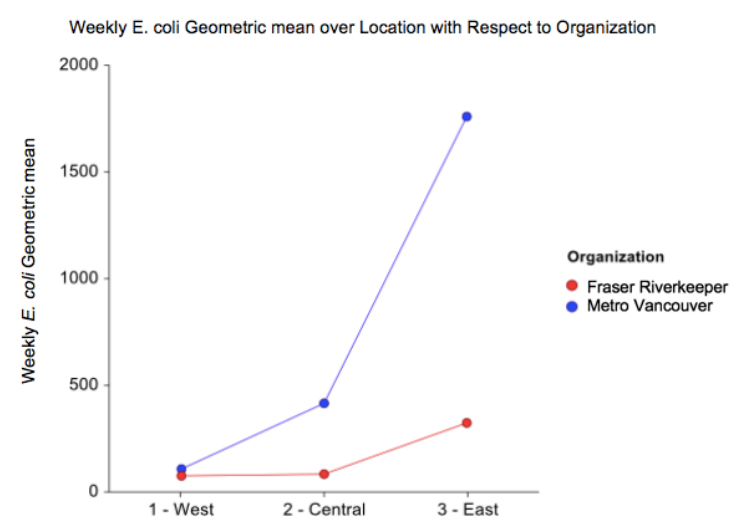

Figure 6: NCSS graph results of MANOVA.

This study agrees with previous studies in False Creek in a myriad of instances. To start, this study confirms the regional trend of False Creek with the Eastern region being most polluted. This finding was found by Antony et al. (2015) where higher $E$. coli counts in the Eastern bay indicated a lack of flushing and dilution. In addition to lack of flushing, the impact of CSOs and stormwater outfalls along the eastern end may also impact these E. coli levels (Balanced Environmental Services, 2010). This is reiterated by Hall et al. (1999) who found the Crowe St. East CSO required the largest dilution compared to other Vancouver CSOs to mitigate its impact. Seeing as the East region has the highest $E$. coli count of all regions, it may be contributing to the negative public perception of False Creek. Being along a populated walking path, its condition may have impacted the results of BCMOE's (2006) survey where ninety-five percent of respondents felt the water quality in False Creek was poor.

When looking at the timeline of $E$. coli counts it appears they steadily increase until September in which the E. coli counts begin to decrease, this aligns with different explanations regarding E. coli in False Creek. The first relation of these results may be indicative of illegal boater discharge into the bay as this aligns with traditional boating season (Gray et 
al., 2011). As boating season ends in September so would discharge into False Creek which would lead to decreased $E$. coli levels. This also coincides with findings by Hornor (2017) and Cummings (2016) who agreed illegal disposal by boaters was a contributing factor to the high E. coli counts in False Creek. If not the impact of illegal sewage disposal, it may indicate the impact of increasing temperatures and geometric counts rising until the beginning of September when temperatures decrease. This would agree with Antony et al. (2015) who took an E. coli count over a twelve-month period and found significantly higher levels in the summer compared to winter months. This also corroborates previous data published by Vancouver Coastal Health (2014) which suggested temperature is the predominant limiting factor to $E$. coli proliferation.

In regard to alpha errors, seeing as the collection location for Metro Vancouver and Fraser Riverkeeper do not all overlap this may contribute to an inaccurate comparison [See Figure 1 and 2]. This would agree with a study where $E$. coli counts varied depending on where the sample was collected (Antony et al. 2015). Fraser Riverkeeper collects samples from seven locations, whereas Metro Vancouver collects samples from twelve different locations to generate a representation of the West, Central and East locations of False Creek. Though Fraser Riverkeeper locations were matched to the closest Metro Vancouver location to compare E. coli counts between regions in False Creek, an exact comparison could not be assessed due to the nature of the secondary data. Another contributing factor pertaining to secondary data is that one must assume proper techniques have been used. This analysis may have been impacted by undisclosed errors, inconsistent sampling techniques or a poor validity in measurements (Johnston, M., 2017). A final barrier posed by secondary data is that this came from two unique organizations which did not collect data in a uniform manner. Though both organizations analyzed samples using IDEXX Colilert system, samples were collected at different depths, locations and time.

Additionally, each organization had a different policy when it came to resampling, which led to inconsistent practices.

In regard to beta errors, though both organizations collect samples on a weekly basis during the summer. Metro Vancouver collects samples from May to September, whereas Fraser Riverkeeper collects samples from July to December. This means the window of comparison rests between July and September giving a sample size of thirteen. Had the organization overlapped more, a greater sample size would have led to more robust results. Additionally, seeing as this is Fraser Riverkeeper's inaugural year of sampling, this also reduced sample size as there is only one season to compare. This will prevent a normal distribution and increase the chances of a beta error.

\section{KNOWLEDGE TRANSLATION AND RECOMMENDATIONS}

The results of this experiment can be used to adjust the practice of both Metro Vancouver and Fraser Riverkeeper. Though Fraser Riverkeeper strategically chose contrasting locations to compliment the data collected by Metro Vancouver, they may consider choosing similar locations to first understand if the data they collected is truly representative and equivalent to Metro Vancouver before selecting contrasting locations which are more likely to lead to different results. Additionally, they may consider having an on-site inspection with the Enhance Water 
Quality Assurance [EWQA] Program to assess their sampling methods and lab analysis procedure.

EWQA acts on behalf of the Ministry of Health to ensure that microbiological testing of drinking water meets established standards and follow laboratory practices. This includes working with private and public organizations to conduct public health audits, training and monitoring (Prystajecky, 2013).

This study also impacts how Metro Vancouver and Vancouver Coastal Health Authority consider the use of Fraser Riverkeeper as a reliable and equivalent source to refer to. Seeing as the results were statistically different, neither party can confidently refer to the other as a comparable reference. Perhaps upon further review of Fraser Riverkeeper's sampling and laboratory analysis, public funds can aid their sampling efforts in other locations of public health concern. For example, in regions where labour efforts are limited, Fraser Riverkeeper can collect and analyze samples on their local health authority's behalf. This may alleviate the economic burden from governmental bodies while still providing educational resources for the public.

Finally, this paper may be of use when it comes to formulating guidelines which outline acceptable sources to refer when assessing the characteristics of a body of water. For example, should Healthy Authorities or the BCCDC recommend the public to refer to the Fraser Riverkeeper or other none governmental sources as a resource when wanting to assess the water quality of False Creek?

\section{LIMITATIONS}

The majority of limitations stem from the use of secondary data as the basis of this study. A limitation from using secondary data comes with there being a lack of familiarity with the exact methods of data collection. This was a hurdle to overcome when interpreting and organizing data for statistical analysis. A second limitation of this study was this lack of overlap in terms of when and precisely where data was collected. With one organization sampling from April to September and another from July to November, this reduced the sample size of this study. Had the organizations sampled over the same period, for example from April to November the sample size would have nearly doubled. This would have made the results of this study more robust. Also, if the sampling was done in exact same locations on exactly the same day, then it would be a more accurate comparison. Finally, time was identified as another limitation of this study. Had this study been less constrained, a more thorough evaluation on the methodology of each organization may have been possible. This is because an opportunity to shadow the collection of samples from each organization may have been taken, however since this study was conducted over the winter months, neither organization were actively sampling.

Though the use of secondary data is needed, this study recommends an extended deadline to provide an opportunity to shadow each organization and thus obtain a better characterization of the methodologies used.

\section{FUTURE RESEARCH}

Some interesting future student projects that can be conducted based on this research study include:

- Repeating this study the following year to confirm or refute the results that were obtained is this study. Additionally, one 
could compare the organizations over two years to have a higher number of replicates.

- $\quad$ By using this data and seeing how E. coli counts change following major Vancouver events such as the Honda Celebration of Lights (CITE), Canada Day or other events where boats are expected to frequent False Creek in the summer. If there is a change in $E$. coli counts, this may help indicate and quantify the impact illegal boater sewage disposal has on False Creek.

- Repeating this study in another location, for example if Fraser Riverkeeper were to expand their testing in another region where recreational water is analyzed. For example, Trout Lake in Vancouver, BC or Macaulay Point in Victoria, BC.

- $\quad$ Repeating this study in Toronto, Ontario where Eat, Drink, Swim originally began water sampling through the Toronto Harbour Water Monitoring Program and compare the results to sampling conducted by Toronto Public Health. Seeing as this program started in 2015 this study could compare up to three years of data.

\section{CONCLUSIONS}

False Creek serves as a community hub where members of the public frequent particularly in the warmer seasons of Vancouver. As a popular recreational body of water, it must be assessed for the risk it poses to the public. This is important as Health Canada (2012) estimates 400,000 Canadians fall ill every year from swimming in polluted waters. By sampling False Creek, public health officials can better communicate to the public the level of risk associated with frequenting False Creek. This may include warnings and closures to the public to reduce waterborne illnesses. Waterborne illness is not only a significant burden to one's health but also adds unneeded strains to society as a whole. Though public health officials are required by law to assess the risk in False Creek, Fraser Riverkeeper is a nonprofit organization that is seeking to supplement and fill a gap in this risk assessment by also sampling False Creek. This may help the public by providing more information but may also cloud their judgement by not knowing which source to refer to. In this study, the results suggest both organizations can characterize the general trends of False Creek when predicting the regional differences of False Creek with a gradient of increasing E. coli counts from West to East (Antony et al., 2015). However, when compared amongst each other, the organizations differ significantly with Metro Vancouver finding greater E. coli counts than Fraser Riverkeeper. This may have been due to differences between the sampling practices of each organization as they differed in sample location, depth and time of collection.

The information obtained in this study can be applied as a means to educate the public in determining whether or not to frequent the waters in False Creek. This may also be utilized to further develop studies pertaining to the microbiological characteristics of False Creek and how to accurately assess the risk it poses to the public. Additionally, further assessment of Fraser Riverkeeper may prove to be a reliable resource for Health Authorities to use. This may include funding recreational water sampling and analysis to reduce the economic burden of governmental bodies.

\section{ACKNOLEDGEMENTS}


The author would like to acknowledge Lorraine McIntyre from BCCDC for the providing valuable resources, guidance and also proposing this research project. In addition, the author would like to thank Helen Heacock for her ongoing support during the study and for providing valuable advice.

\section{ABBREVIATIONS}

In order of appearance:

$\begin{array}{ll}\text { E. coli } & \text { Escherichia coli } \\ \text { MPN } & \text { Most Probable Number } \\ \text { FIB } & \text { Fecal Indicator Bacteria } \\ \text { RWI } & \text { Recreational Waterborne Illnesses } \\ \text { CSO } & \text { Combined Sewer Overflows } \\ \text { BCMOE } & \text { British Columbia Ministry of } \\ \text { Environment } & \\ \text { MV } & \text { Metro Vancouver (Table 1 only) } \\ \text { FRK } & \text { Fraser Riverkeeper (Table 2 only) } \\ \text { EWQA } & \text { Enhance Water Quality Assurance }\end{array}$

Program

\section{COMPETING INTEREST}

The authors declare that they have no competing interests.

\section{REFERENCES}

1. Antony, A., Hsu, D., Chen, E., Chen, J., \& Sondergeld, O. (2015). Seasonal, spatial and source variation of E. coli counts in False Creek, British Columbia. https://doi.org/10.14288/1.0074572

2. Balanced Environmental Services. (2010). Burrard Inlet Point Source Discharge Inventory. Prepared for the Burrard Inlet Environmental Action Program.

3. Banerjee, A., Chitnis, U. B., Jadhav, S. L., Bhawalkar, J. S., \& Chaudhury, S. (2009). Hypothesis testing, type I and type II errors. Industrial psychiatry journal, 18(2), 127-31.

4. BC Ministry of Environment. (2006). Assessment of Bacteriological Indicators in False Creek. Retrieved from:
http://a100.gov.bc.ca/pub/eirs/finishDownlo adDocument.do? subdocumentId=2728

5. British Columbia Ministry of Environment and Climate Change Strategy. (2017). B.C. Recreational Water Quality Guidelines:

Guideline Summary. Water Quality Guideline Series, WQG-02. Prov. B.C., Victoria B.C. Retrieved from:

https://www2.gov.bc.ca/assets/gov/environm ent/air-land-water/water/waterquality/wqgswqos/approved-

wqgs/recreational_water_quality_guidelines bcenv.pdf

6. Canadian Council of Ministers of the Environment. (2008). Recreational Water Quality Guidelines and Aesthetics. Retrieved from: http://ceqgrcqe.ccme.ca/download/en/316.

7. Crowe, B., \& Eng, P. (2014). Eliminating Combined Sewer Overflows from

Vancouver's Waterways. Retrieved from http://www.metrovancouver.org/events/com munity-

breakfasts/Presentations/BrianCroweCityofVancouver-EliminatingCSOsApril15breakfast.pdf

8. Cummings, C. (2016). Water Quality in False Creek : For Policy Makers. https://doi.org/10.14288/1.0342792

9. Eagland, N. (2018). Huge False Creek herring spawn surprises conservationists Vancouver Sun. Retrieved October 10, 2018, from https://vancouversun.com/news/localnews/false-creek-herring-spawn-exceeds-1billion-surprises-conservationists

10. Fraser Riverkeeper. (2018). False Creek Water Monitoring Program. Retrieved from: http://www.fraserriverkeeper.ca/false_creek water monitoring

11. Gray, D. L., Canessa, R. R., Keller, C. P., Dearden, P., \& Rollins, R. B. (2011). Spatial characterization of marine recreational boating: Exploring the use of an on-thewater questionnaire for a case study in the Pacific Northwest. Marine Policy, 35(3), 286-298.

12. Hall, K. J., McCallum, D. W., Lee, K., \& Macdonald, R. (1998). Characterization and aquatic impacts of combined sewer overflows in Greater Vancouver, British Columbia. Water Science and Technology, 38(10), 9-14. https://doi.org/10.1016/S02731223(98)00727-6 
13. Health Canada. (2012). Guidelines for Canadian Recreational Water Quality Third Edition.

14. Hornor, L. (2017). Fraser Riverkeeper's Recommendations for a Swimmable Vancouver - Fraser Riverkeeper. Retrieved October 8, 2018, from http://www.fraserriverkeeper.ca/frk_swimm able_vancouver

15. Johnston, M. P. (2017). Secondary data analysis: A method of which the time has come. Qualitative and quantitative methods in libraries, 3(3), 619-626.

16. Passerat, J., Ouattara, N. K., Mouchel, J.-M., Vincent Rocher, \& Servais, P. (2011). Impact of an intense combined sewer overflow event on the microbiological water quality of the Seine River. Water Research, 45(2), 893-903.

https://doi.org/10.1016/J.WATRES.2010.09. 024

17. Parker, J. K., McIntyre, D., \& Noble, R. T. (2010). Characterizing fecal contamination in stormwater runoff in coastal North Carolina, USA. Water Research, 44(14), 4186-4194. https://doi.org/10.1016/J.WATRES.2010.05. 018

18. Prystajecky, N. (2013). Enhanced Water Quality Assurance (EWQA). Retrieved from: http://lmlabs.phsa.ca/Documents/232EWQA BrochureMay2013.pdf

19. NCSS Statistical Software. NCSS 12 data analysis [Internet]. (2018). Available from: https://www.ncss.com/software/ncss/

20. Sauro, \& J. Lewis, J.R. (2012) "Quantifying the User Experience: Practical Statistics for User Research " Morgan Kaufmann Publishers

21. World Health Organization. (2006). Guidelines for Safe Recreational Water Environments Volume 2: Swimming Pools and Similar Guidelines for safe recreational water environments. Volume 2, Swimming Pools and Similar Environments. Retrieved from http://apps.who.int/iris/bitstream/handle/106 65/43336/9241546808 eng.pdf? sequence $=1$ \&isAllowed $=\mathrm{y}$

22. Vancouver Coastal Health. (2014). Beach Water Quality Report. Retrieved from: http://www.vch.ca/your-environment/waterquality/recreational-water/beach- waterquality-report $/ 30$
23. Vancouver Coastal Health. (2017). About Us. Retrieved from: http://www.vch.ca/about-us

24. Zadeh, P., Hosseini, R., \& Sra, S. (2016, June). Geometric mean metric learning. In International conference on machine learning (pp. 2464-2471). 